\title{
AS NAÇÕES DE MARACATU E OS GRUPOS PERCUSSIVOS: AS FRONTEIRAS IDENTITÁRIAS
}

\author{
Ivaldo Marciano de França Lima*
}

$\mathrm{H}$ á, na atualidade, uma grande quantidade de grupos musicais reproduzindo a sonoridade dos maracatus-nação pernambucanos espalhados pelo Recife e mundo afora. Atribui-se tal fato ao advento e sucesso do movimento Mangue Beat nos anos 1990 e à atuação do grupo parafolclórico Maracatu Nação Pernambuco que, nos anos anteriores, positivou a imagem do maracatu perante a classe média recifense e sociedade pernambucana em geral. Em outros trabalhos, venho enfatizando também a ação de muitos maracatuzeiros e maracatuzeiras que "insistiram" em manter suas nações, apesar das muitas adversidades, o que contribuiu para a permanência desses grupos na cena cultural pernambucana. Muitos desses ilustres maracatuzeiros e maracatuzeiras foram objeto de discussão em recente trabalho publicado. ${ }^{1}$

Esses maracatus são distintos entre si e podem ser agrupados em duas grandes categorias. ${ }^{2}$ A primeira é a dos denominados maracatus-nação, formados majoritariamente por comunidades de negros e negras que compartilham práticas e costumes, dentre os quais se destacam as

* Professor da Universidade do Estado da Bahia. ivaldomarciano@yahoo.com.br

Ivaldo Marciano de França Lima, Maracatus do Recife: novas considerações sob o olhar dos tempos, Recife: Bagaço, 2012.

2 Essa categorização não inclui os maracatus de orquestra, ou de baque solto, uma vez que inexistem, até o momento, grupos que reivindiquem sua prática fora de Pernambuco. 
religiões de divindades e de entidades. ${ }^{3}$ Devido ao sucesso dos maracatus nos anos 1990, uma categoria que não pode ser classificada como nação, já que não possui vínculos comunitários, ganha maior visibilidade. Trata-se de grupos percussivos formados normalmente por jovens brancos de classe média, interessados, sobretudo, em fazer música. É importante salientar que a maior parte desses grupos não tem cortejo, elemento indispensável na caracterização do maracatu-nação.

Há aproximadamente em torno de cinquenta desses grupos que se apresentam e ensaiam ao longo do ano na cidade do Recife e região metropolitana, disputando espaços com vinte e oito maracatus-nação. ${ }^{4} \mathrm{Um}$ encontro semanal congrega muitos integrantes desses grupos, conhecido entre os jovens batuqueiros como Traga a Vasilha, que tem angariado sucesso e legitimidade entre os que frequentam o Bairro do Recife às sextas-feiras, dia em que se reúnem. Fora de Pernambuco, há grupos que se reivindicam como maracatus, dotados de força e visibilidade significativa. No Sudeste, esses grupos adquirem relativa visibilidade, sobretudo por estarem em "grandes vitrines" culturais e por disporem de recursos que lhes permitem ter um maior alcance, gravando CDs, realizando apresentações em casas de shows famosas e arrebanhando simpatizantes.

\footnotetext{
3 Estou utilizando os termos "religião de entidades e de divindades" em substituição aos conceitos "afro-brasileiro", "afrodescendente" e "matriz africana", utilizados largamente pelos pesquisadores e estudiosos para nomear religiões que possuem elementos indígenas, cristãos e kardecistas, como é o caso da jurema e da umbanda. Essas religiões, quando recebem a denominação exclusiva de "afro", deixam invisibilizadas as contribuições "não negras".

4 Há grupos percussivos em diversos estados do país, a exemplo do Rio de Janeiro, São Paulo, Paraná, Santa Catarina, Rio Grande do Sul, Minas Gerais, Paraíba e Ceará. Só em Pernambuco, somam-se mais de cinquenta grupos. Também existem grupos percussivos em outros países, a exemplo da Alemanha, França, Rússia, Estados Unidos, Canadá, Espanha, Portugal, Japão, dentre outros. A cada dois anos, ocorre na Europa um encontro internacional de grupos e pessoas que fazem maracatu. No Brasil, na região Sudeste, também ocorrem tais encontros, em geral organizados pelos grupos paulistas. Alguns desses grupos percussivos “internacionais” já dispõem de registros sonoros e, em alguns casos, se constituem em grupos com mais de quinze anos de existência, a exemplo do Stern der Elbe, da Alemanha. Também há grupos percussivos brasileiros dotados de CDs, a exemplo do Rio Maracatu e de diversos grupos paulistas. São estes os maracatus-nação existentes em Pernambuco: Almirante do Forte, Aurora Africana, Axé da Lua, Cambinda Estrela, Encanto da Alegria, Encanto do Dendê, Encanto do Pina, Estrela Brilhante do Recife, Estrela Dalva, Estrela de Olinda, Gato Preto, Leão da Campina, Linda Flor, Nação de Luanda, Oxum Mirim, Porto Rico, Raízes de Pai Adão, Sol Nascente, Tigre, Tupinambá, Lira do Morro da Conceição, Rosa Vermelha, Leão de Judá, Centro Grande Leão Coroado, Cambinda Africana, Elefante, Estrela Brilhante de Igarassu e Leão Coroado de Águas Compridas. Quase todos os grupos, exceto os quatro últimos, são filiados à Associação dos Maracatus Nação de Pernambuco (AMANPE).
} 
Entre os maracatuzeiros, seja das nações ou dos novos grupos denominados percussivos, há uma forte tensão em torno da legitimidade. Pode-se dizer que essa tensão é o resultado de uma disputa pelo mercado cultural, inflacionado pela grande quantidade de grupos. Nessa disputa, os argumentos giram em torno daquilo que legitima ou deslegitima os "autênticos" maracatus. A proliferação dos grupos percussivos tem sido vista como uma ameaça à "tradição" e como uma descaracterização dos "autênticos" grupos populares, esses sim mantenedores de uma tradição consubstanciada numa vinculação com um terreiro da religião dos orixás. Muitos velhos maracatuzeiros insistem em afirmar que esses novos grupos não podem ser chamados de maracatus, pois não se constituem numa nação. Esse conflito traz em seu bojo algumas interrogações: O que faz um maracatu "tradicional" do Recife ser uma "nação"? Quais as suas diferenças em relação aos demais grupos percussivos pernambucanos e brasileiros de modo geral?

Ao percorrer a bibliografia sobre a relação entre identidade étnica e a formação das "nações" entre os escravos, comecei a me interrogar quais poderiam ser os vínculos existentes entre essas antigas nações de escravos e as nações de maracatu. O desafio lançado foi o de investigar as razões que levaram à permanência da categoria "nação" para designar tais grupos. Essa designação teria mantido os mesmos sentidos dos séculos XVIII e XIX, ou teria sido ressignificada de acordo com as práticas sociais e culturais de cada um dos grupos? Essa não é uma questão de menor importância, uma vez que nos remete à discussão das permanências da história e das transformações que nela ocorrem. ${ }^{5}$

Para mostrar a complexidade em que a questão está envolvida, é necessário esclarecer que o termo "nação" é usado ainda hoje, e o foi ao longo do século XX, com duplo significado.

O primeiro diz respeito a diversas manifestações culturais, tais como maracatus, sejam eles os de baque virado ou solto, caboclinhos e bois. Na forma de se referir das pessoas que participam dessas manifes-

Carlo Ginzburg, História noturna: decifrando o sabá, São Paulo: Companhia das Letras, 1998. Neste trabalho, Ginzburg interroga-se sobre as permanências de mitos, ritos e símbolos em diferentes regiões do mundo. 
tações, cada grupo constitui uma nação particular. O grupo caboclinho Canindés, localizado na Bomba do Hemetério (zona norte do Recife), por exemplo, considera-se uma nação diferente e, muitas vezes, rival do caboclinho Sete Flechas (localizado em Água Fria, também na zona norte do Recife). Do mesmo modo, podemos nos referir aos maracatus de orquestra e nação. Cada grupo constitui uma nação diferente.

A segunda acepção do termo diz respeito à sua utilização entre os praticantes das religiões de divindades. Na religião dos orixás (xangô ou candomblé), um terreiro constitui-se parte (membro) de uma nação, mas o terreiro vizinho também pode integrar a mesma nação. Desse modo, a nação no candomblé e no xangô não se refere a um grupo específico, mas a uma série de práticas comuns que possuem uma linhagem, algumas das quais consubstanciadas em mitos de origem "africana", como é o caso da nação nagô, no xangô pernambucano, ou queto, no candomblé baiano. Assim, pode-se afirmar que a utilização do termo "nação" entre as manifestações da cultura negra não é decorrente de seu uso na religião, como poderia se afirmar à primeira vista, ou como é corrente no discurso quotidiano entre os maracatuzeiros (como se uma "nação" de maracatu fosse também uma nação de xangô). Um maracatu possui (ou pode possuir) em seu interior membros de diversas nações religiosas. Os significados aludem a práticas distintas, e pode-se concluir que o sentido com que a palavra "nação" era utilizada nos séculos XVIII e primeira metade do século XIX mudou no decorrer da segunda metade do século XIX e em todo o XX. Não dispomos de fontes para acompanhar essa mudança em sua complexidade, mas há indícios suficientes para aventar algumas hipóteses. ${ }^{6}$

\section{Trânsitos entre o saber acadêmico e o fazer popular na busca pela legitimidade}

Os principais intelectuais que pesquisaram os maracatus-nação da atua-

\footnotetext{
6 Apesar de ser assunto já muito referido, nunca é demais lembrar as discussões levadas a efeito por Carlo Ginzburg a respeito da importância do método indiciário para o conhecimento histórico. Ver: Carlo Ginzburg, Mitos, emblemas, sinais: morfologia e história, São Paulo: Companhia das Letras, 1989.
}

74 Afro-Ásia, 49 (2014), 71-104 
lidade em Pernambuco foram os folcloristas, e não há ainda, no âmbito acadêmico, uma produção abundante sobre o tema, apesar dos recentes trabalhos que surgem a cada ano. Atualmente, Roberto Benjamin (ex-presidente nacional da Comissão Nacional do Folclore) e Leonardo Dantas são os mais conhecidos e ativos intelectuais que escrevem sobre o maracatu-nação e outras formas de manifestação cultural pernambucana. Em seus trabalhos, fruto de suas longas carreiras, prevalece a ideia de que os maracatus-nação possuem uma origem possível de ser conhecida e de que são dotados de práticas e costumes que se repetem há anos, resultado da manutenção de uma tradição há muito existente, ${ }^{7}$ argumentando, desse modo, no campo do folclore. A partir de seus trabalhos, poderia se pensar que a permanência da palavra "nação" se deveria a uma continuidade dos usos do passado, como se tivessem o mesmo significado. Essa continuidade é atribuída à origem dos maracatus, com a coroação dos reis e rainhas do Congo.

Desde Pereira da Costa, passando por uma série de cronistas, literatos e jornalistas, foi se firmando no campo do folclore um modelo do que é o maracatu-nação. Não vou aqui voltar a uma discussão já enfrentada em outros trabalhos, mas me parece que essa questão pode ser alargada se nos perguntarmos se e como a produção desses intelectuais tem influenciado a prática popular. Na historiografia brasileira, essa mesma questão foi magnificamente enfrentada por Beatriz Góis Dantas, em seu livro Vovó nagô e papai branco, no qual analisa as influências dos antropólogos na construção da ideologia da pureza nagô, bem como a utilização desse discurso por parte dos praticantes da religião na busca pela legitimidade e por uma fatia maior no mercado das almas. ${ }^{8}$ Quando se pensava que essa era uma questão há muito superada, Stefânia Capone demonstrou que o "mito" da pureza nagô persiste entre os praticantes

\footnotetext{
Para conferir alguns dos trabalhos dos autores em questão, ver: Leonardo Dantas da Silva, “A calunga de Angola nos maracatus do Recife", in Leonardo Dantas da Silva (org.), Estudos sobre a escravidão negra (Recife: Massangana, 1988, v. 2); Leonardo Dantas da Silva, "A corte dos reis do Congo e os maracatus do Recife", Notícia bibliográfica e histórica, n. 184 (2002), pp. 43-64; Leonardo Dantas da Silva, "A instituição do rei do Congo e sua presença nos maracatus", in Leonardo Dantas da Silva (org.), Estudos sobre a escravidão negra; Roberto Benjamin, "Congos da Paraíba", Cadernos de Folclore, n. 18, Rio de Janeiro: FUNARTE, 1977.

8 Beatriz Góis Dantas, Vovó nagô e papai branco: usos e abusos da África no Brasil, Rio de Janeiro: Graal, 1988.
} 
e é corroborado por uma série de antropólogos que também legitimam os campos em que pesquisam. Em outras palavras, Capone se interroga sobre as razões que levam os antropólogos a recorrentemente estudarem os mesmos terreiros, ignorando uma quantidade enorme de outros que não poderiam se encaixar no modelo. ${ }^{9} \mathrm{O}$ que essas questões podem nos dizer sobre os maracatus?

Nesse caso, estamos propriamente no campo do folclore, em que as categorias de análise mais valorizadas são a "tradição" e sua "manutenção", o que redundaria na autenticidade de certas práticas (conformes à tradição) e na sua pureza. É evidente que, assim como em outros estados do país, os folcloristas em Pernambuco não ficaram adstritos aos seus escritórios e foram para as ruas, interferindo nas práticas e manifestações da cultura popular. ${ }^{10}$ Disso redundou um contexto muito semelhante ao ocorrido na questão acima colocada a respeito da religião dos orixás e da atuação dos antropólogos. No caso dos folcloristas, formou-se um saber consagrado e cristalizado em que normas e modelos de práticas e manifestações da cultura popular são definidos. No entanto, essas questões têm trânsito de mão dupla, e importa para nosso objetivo discutirmos como os populares, ou melhor, os maracatuzeiros, vão se inserir nessa discussão e se apropriar desse discurso em busca de legitimidade.

$\mathrm{Na}$ visão de grande parte desses intelectuais, o que define a fronteira entre os maracatus-nação e os grupos percussivos é a manutenção de uma tradição há muito repetida e consubstanciada na relação entre a nação e a religião dos orixás. Tanto esta última quanto o maracatu, com suas "origens africanas", são postos como naturalmente relacionados. Um maracatu "legítimo e tradicional" deve, portanto, possuir uma ligação com um terreiro de xangô (que alguns dos atuais praticantes dessa religião denominam candomblé), ter um rei e uma rainha de cor negra que, de preferência, sejam "feitos no santo" (que sejam iniciados na religião dos orixás) para que o grupo tenha o status de "autêntico ou tradicional".

Stefania Capone, A busca da África no candomblé: tradição e poder no Brasil, Rio de Janeiro: Pallas/Contracapa, 2004.

${ }^{10}$ Luís Rodolfo Vilhena, Projeto e missão: o movimento folclórico brasileiro (1947-1964), Rio de Janeiro: Funarte/FGV, 1997; Katarina Real, Eudes, o rei do maracatu, Recife: FUNDAJ/ Massangana, 2001.

76 Afro-Ásia, 49 (2014), 71-104 
Nessa perspectiva, a autenticidade e tradicionalidade serão maiores ainda se o rei e a rainha forem autoridades sacerdotais e possuidores de vínculos familiares antigos, se forem filhos e filhas de homens e mulheres reconhecidamente antigos no "santo", para que o maracatu tenha o perfil de matriarcado ou patriarcado. Sem a ligação com o terreiro de xangô, o maracatu-nação terá sua legitimidade comprometida; se, porventura, houver liames religiosos desse grupo com outra religião (a exemplo da jurema ou da umbanda), isso será sinal de que aquela tradição e pureza estarão "se perdendo", ou "se descaracterizando".

Roberto Benjamin foi um dos folcloristas empenhados em garantir que o Maracatu Nação Leão Coroado tivesse sua continuidade assegurada após a morte de seu principal mantenedor e articulador, o famoso Luiz de França. Benjamin e outros membros da Comissão Pernambucana do Folclore, preocupados com o "enfraquecimento dos maracatus", trataram de garantir que a sucessão ocorresse de modo que a "tradição não se perdesse". ${ }^{11}$ Nesse contexto, Afonso, afamado ogã de alguns terreiros de xangô "tradicionais", foi o escolhido para dar continuidade ao grupo, apesar de os antigos integrantes do maracatu bem como os familiares "adotivos" de Luiz de França não terem sido ouvidos ou considerados. Nesse processo de transição autoritária, o Leão Coroado "mudou" da comunidade em que estava sediado há mais de quarenta anos, o Córrego do Cotó, para Águas Compridas, e a filha adotiva de Luiz de França, Mana, que, segundo ele, poderia dar continuidade ao maracatu, foi totalmente excluída do processo.

Por mais criticável que seja o conceito de tradição "mantida com

\footnotetext{
${ }^{11}$ Para conferir parte das opiniões de Benjamin sobre Afonso e o Leão Coroado, ver: Roberto Benjamin, "Dona Santa e Luiz de França: gente dos maracatus", in Vagner Gonçalves da Silva (org.), Memória afro-brasileira: artes do corpo (São Paulo: Selo Negro, 2004). Discuti essa questão, mostrando que existem outras versões sobre o processo sucessório desse maracatu, a exemplo do desejo de Luiz de França em entregar o Leão Coroado a sua filha adotiva, além de declarações suas afirmando em outros momentos que desejava ter o Leão Coroado no "museu", junto com o Elefante de Dona Santa. Para conferir, ver: Ivaldo Marciano de França Lima, Identidade negra no Recife: maracatus e afoxés, Bagaço: Recife, 2009. Sobre as declarações de Luiz de França e o seu desejo em ver o Leão Coroado no museu, ver: "Um leão sem coroa", Diário de Pernambuco, 14 de janeiro de 1996, Caderno Viver, p. 1. Em 2010, ocorreu uma assembleia dos antigos integrantes do Leão Coroado, juntamente com os netos e a filha adotiva de Luiz de França, que decidiram dar continuidade ao maracatu. Há, na atualidade, portanto, dois grupos homônimos que disputam o legado do antigo Leão Coroado de Luiz de França.
} 
base na repetição, e possível de ser localizada no tempo e no espaço" (com uma história linear, visto ter uma origem única), ele é ainda hoje dotado de força suficiente para que a sociedade pernambucana, representada nas Secretarias de Cultura e Turismo (além dos poderes públicos em geral), possa cassar o direito de determinados grupos se apresentarem no carnaval. E a tradição está representada pelo maracatu-nação! Um maracatu (ou grupo percussivo) como o Cabra Alada ou o Batuque Estrelado, mesmo possuindo uma corte real e expressivo número de batuqueiros, não pode participar do concurso de maracatus-nação organizado pela Prefeitura da Cidade do Recife ou da tão famosa Noite dos Tambores Silenciosos. ${ }^{12}$ Para um maracatu, não ser "tradicional" significa, nesse contexto, ter diminuída sua importância simbólica e, ao mesmo tempo, perder oportunidades de ganhos significativos, comprometendo a sua viabilidade e existência. Não é de se estranhar, portanto, que todos os maracatus-nação - por meio de seus integrantes - afirmem possuir vínculos com a religião dos orixás e se reivindiquem tradicionais. Se, em um passado não muito distante, essa relação era ocultada, hoje é não só proclamada como também se constitui em principal argumento para definir os maracatus-nação e os "descaracterizados" ou "estilizados". Essa disputa pode ser vista como um alargamento do campo, em que novos grupos buscam legitimidade, mas não dispõem ainda de capital simbólico para se inserirem no campo nem modificarem as regras que o definem. ${ }^{13}$

Entre os populares, é possível perceber-se o poder do discurso sobre a tradição, consubstanciado na ideia de uma obrigatória relação do maracatu com o terreiro. Os grupos percussivos formados por jovens oriundos, em sua maioria, das camadas médias urbanas da região metropolitana do Recife são, grosso modo, denominados estilizados, e alguns sofrem rejeição dos mais idosos, que afirmam serem aqueles grupos um perigo para a "tradição do maracatu". Em suma, para um maracatu ser

\footnotetext{
12 Sobre a Noite dos Tambores Silenciosos, ver: Isabel Cristina Martins Guillen, "Xangôs e maracatus: uma relação historicamente construída", Ciências Humanas em Revista, v. 3, n. 2 (2005), pp. 59-72; Isabel Cristina Martins Guillen, "Noite dos Tambores Silenciosos: ritual e tradição entre os maracatus-nação do Recife", Anais Eletrônicos da $25^{a}$. Reunião Brasileira de Antropologia. Goiânia, ABA/UFG/Universidade Católica de Goiás, 2006.

13 Pierre Bourdieu, O poder simbólico, Lisboa: Difel, 1989.
}

78 Afro-Ásia, 49 (2014), 71-104 
considerado "nação", entre seus pares, deve ter uma relação explícita com um terreiro, de preferência da religião dos orixás, e deve estar sediado em uma comunidade. Mas isso não basta. Para que ele tenha plena legitimidade, deve seguir o modelo de maracatu preconizado por alguns intelectuais que escreveram sobre cultura popular, como se fossem os únicos dotados do conhecimento do que é "pureza" e "tradição" nas práticas e nos costumes do "povo pernambucano". Essa relação do maracatu com a religião dos orixás (xangô) ganhou visibilidade a partir do trabalho de Guerra-Peixe, tomado ainda hoje como modelo de tradição entre os maracatus-nação e os intelectuais. ${ }^{14}$

Apesar de todo o questionamento e das acusações de que se desrespeita a tradição, pode-se dizer que há práticas em comum entre os grupos percussivos do país inteiro, algumas das quais constituidoras de legitimidade. Ressalte-se que esses indivíduos construíram essa legitimidade para poder "fazer" maracatu, sem que lhes fosse questionado o fato de estarem fazendo algo que não lhes pertencia, ou que não dispunham da permissão de se apropriar de uma cultura reconhecidamente centenária e, ao mesmo tempo, com status "tradicional". Os grupos percussivos em questão (os do Rio de Janeiro, que observei, e os de Pernambuco que conheço, sobretudo) possuem discursos de legitimidade, práticas norteadoras e constituem identidades. Ressalte-se o fato de que alguns dos componentes desses grupos percussivos se dizem membros de nações "tradicionais" (e participam, no carnaval, dos batuques dos maracatus-nação), tornando a tarefa de definir as fronteiras entre os grupos percussivos e os maracatus-nação muito mais complexa. ${ }^{15}$ Como estabelecer essas fronteiras? Elas existem na realidade? Deveria ser aceita a forma pela qual alguns desses grupos percussivos se veem, adotando-se uma

\footnotetext{
14 César Guerra-Peixe afirmou que os maracatus de orquestra estavam ligados à jurema, enquanto os de baque virado (nação) se relacionavam com o xangô. A partir de seu trabalho, essa relação se tornou "natural" e tem sido repetida como se constituísse uma regra geral. Ver: Guerra-Peixe, Maracatus do Recife, Recife: Prefeitura da Cidade do Recife/Irmãos Vitale, 1980.

15 Para as diferenciações das experiências entre grupos e indivíduos no processo de constituição identitária, ver: Simona Cerutti, "Processo e experiência: indivíduos, grupos e identidades", in Jacques Revel (org.), Jogos de escala: a experiência da microanálise (Rio de Janeiro: Fundação Getúlio Vargas, 1998). Para se livrarem da acusação de que simplesmente se apropriam da cultura popular, os grupos percussivos costumam argumentar que contribuem para a sobrevivência dos maracatus e, consequentemente, da tradição.
} 
prática bastante comum da Antropologia contemporânea, que é a de analisar as práticas a partir do ponto de vista do "nativo"? Ou deve-se efetivamente tentar entender os jogos discursivos destes "jovens batuqueiros" em busca de espaço e legitimidade?

Para responder a algumas dessas questões, acredito que a história dos usos e sentidos de "nação" pode nos ajudar a entender os processos da contemporaneidade, por mostrar que tais usos foram constantemente ressignificados, atendendo a interesses diversos bem como circunstanciados historicamente. E não deixam de sê-lo ainda hoje.

\section{O conceito de nação: História e Historiografia}

Ao apresentar o trabalho de Fredrik Barth, Tomke Lask observa que uma de suas principais preocupações a respeito da teoria diz respeito ao fato de que ela tem de se adaptar à realidade, e não o inverso:

Em que momento da pesquisa a posição teórica do antropólogo deve se tornar predominante? Quando, e de que maneira transformar a terminologia dos nativos em terminologia técnica, quer dizer, em conceitos sociológicos? Segundo Barth, não se deve passar cedo demais para essa transformação porque esses termos dependem do contexto local em que estão inseridos e podem ter significados variados numa mesma sociedade. ${ }^{16}$

Sem dúvida, ao conceito de "nação" que é utilizado no universo dos maracatus se aplicam as observações acima, uma vez que possui diversos significados e que se modificaram historicamente. Em seu uso mais corriqueiro na contemporaneidade, refere-se à tradição iluminista, analisada por Hobsbawn em Nações e nacionalismos desde $1870 .{ }^{17}$ Para seus usos na historiografia brasileira e suas reverberações com as discussões acerca da identidade nacional, um bom apanhado pode ser encontrado no trabalho de Marilena Chauí. ${ }^{18}$

\footnotetext{
16 Tomke Lask, "Apresentação", in Fredrik Barth, O guru, o iniciador e outras variações antropológicas (Rio de Janeiro: Contracapa, 2000), p. 11.

17 Eric Hobsbawm, Nações e nacionalismo desde 1780, Rio de Janeiro: Paz e Terra, 1998.

18 Marilena Chauí, Brasil: mito fundador e sociedade autoritária, São Paulo: Perseu Abramo, 2000.

80 Afro-Ásia, 49 (2014), 71-104
} 
No entanto, outros significados existiram para o termo "nação", bem como existem ainda hoje. Como ficaram invisibilizados durante tanto tempo? Afirmo isso porque é relativamente recente a série de trabalhos acerca da história da escravidão que aponta outros sentidos para a palavra "nação". Para Marina de Mello e Souza, a não percepção dessa questão deve-se ao fato de que os primeiros estudiosos da cultura negra no Brasil, dentre os quais se destaca Nina Rodrigues e seu trabalho Os africanos no Brasil, dividiram os africanos escravizados em dois grandes grupos, os bantos e os sudaneses. Apesar de Nina Rodrigues esmiuçar esses grupos, houve uma tendência à sua homogeneização, presente ainda nos dias de hoje em trabalhos como os de Reginaldo Prandi. ${ }^{19}$

Pode-se afirmar que o trabalho de Mary Karasch constitui um divisor de águas ao mostrar a existência, na cidade do Rio de Janeiro, de diversos grupos étnicos, apontando para a diversidade e a complexidade das relações que esses povos estabeleciam com a sociedade e entre si. O trabalho de Karasch foi, sem dúvida, um dos responsáveis e incentivadores do esmiuçar que a atual historiografia promove no estudo dos grupos de escravos, suas culturas e práticas, tal como discutido pela extensa bibliografia analisada. ${ }^{20}$

Quase um século foi necessário para que a homogeneizadora categoria de "africano", que passou a ser recorrentemente utilizada na segunda metade do século XIX, após o fim do tráfico negreiro, começasse a ser questionada, e os historiadores começassem a pensar sobre quem eram esses africanos, deslocando o olhar do geral para o específico, do macro para o micro. Sem dúvida, não podemos aqui deixar de apontar as contribuições do debate promovido pela Micro-História, que privilegia em sua análise as tramas miúdas e, em se tratando de método, busca reduzir a escala de análise. ${ }^{21}$

\footnotetext{
19 Marina de Mello e Souza, Reis negros no Brasil escravista: história da festa de coroação de Rei Congo, Belo Horizonte: Editora UFMG, 2002, p. 144; Reginaldo Prandi, “A dança dos caboclos: uma síntese do Brasil segundo os terreiros afro-brasileiros", $<$ http://www.fflch.usp.br/sociologia/ prandi/dancacab.rtf $>$, acessado em 11/11/2012; Reginaldo Prandi, "Música de fé, música de vida: a música sacra do candomblé e seu transbordamento na cultura popular brasileira", $<$ http://www. fflch.usp.br/sociologia/prandi/musicafe.rtf $>$, acessado em 11/11/2012.

20 Mary C. Karasch, A vida dos escravos no Rio de Janeiro, 1808-1850, São Paulo: Companhia das Letras, 2000

${ }^{21}$ Jacques Revel, "Microanálise e construção do social", in Revel (org.), Jogos de escala.
} 
Porém, o conceito "africano", assim como o seu caráter homogeneizador, foi fundamental para a transformação dos significados das "nações" de escravos do século XVIII e XIX, e a consolidação de outras, estreitamente relacionadas com as mudanças ocorridas na segunda metade do século XIX, bem como o surgimento das "nações" de candomblé. $\mathrm{Na}$ atualidade, existem grupos de indivíduos organizados pelo país afora que se reivindicam pertencentes a uma nação de candomblé ou de xangô. Dizem essas pessoas (ou um número significativo delas) que são herdeiras das antigas nações trazidas para o Brasil com os escravos. Jeje, nagô, queto, angola, moçambique, cabinda são alguns dos nomes utilizados por esses indivíduos para nomear seus grupos intitulados "nações" e reconhecidos como tal em diversos trabalhos acadêmicos que tiveram as religiões de divindades e de entidades como objeto. A "nação" de xangô ou candomblé é, portanto, vista como herdeira dos escravos que para o Brasil foram trazidos ao longo da vigência do período em que predominou a mão de obra escrava. ${ }^{22}$

A "nação" do período escravista, no entanto, não poderia ser vista ou considerada como um grupo étnico homogêneo, mas uma forma pela qual vários povos foram agrupados e organizados, levando-se em conta o porto em que eram embarcados bem como as afinidades e o compartilhamento de práticas, dependendo da perspectiva em que se observa o processo de criação dessas nações, seja do ponto de vista dos traficantes e senhores, seja do escravo. ${ }^{23}$ Segundo Mariza Soares, as nações aqui criadas não constituíam grupos homogêneos e possíveis de serem confundidos com um grupo étnico. Essas "nações" de escravos possuíam em seu interior indivíduos de diferentes grupos étnicos que eram agrupados a partir da lógica do tráfico negreiro, sendo aqui nomeados de modo que fosse possível ter identificada sua procedência. ${ }^{24} \mathrm{O}$ título do artigo de Mariza Soares define bem a condição das nações aqui existentes: aos escravos que desembarcavam nos portos era imposta uma "nação", que

\footnotetext{
22 Vivaldo da Costa Lima, "O conceito de 'nação' nos candomblés da Bahia", Afro-Ásia, n. 12 (1976), pp. 65-90.

23 Veja-se para a questão: Mariza de Carvalho Soares, "A 'nação' que se tem e a 'terra' de onde se vem: categorias de inserção social de africanos no Império português, século XVIII", Estudos Afro-Asiáticos, v. 2, n. 26 (2004), pp. 303-30.

${ }^{24}$ Soares, "A 'nação' que se tem".

82 Afro-Ásia, 49 (2014), 71-104
} 
doravante lhe imprimiria uma marca tão forte, a ponto de estar presente no seu nome. ${ }^{25} \mathrm{O}$ fato de serem essas nações fruto da lógica do comércio escravista, segundo Mariza Soares, não permitiria afirmar que os escravos não se utilizavam desta nova identidade, pois ressignificaram o sentido das "nações", conferindo-lhe organização social e identitária diversas.

A forma como era constituída a nação ou o local de procedência do escravo não eram isentos de regras ou algo totalmente arbitrário. Os nomes das nações constituíam excelente recurso adotado pelos traficantes e comerciantes de escravos para designar e classificar os africanos traficados da África para a América. ${ }^{26}$ Ao serem desembarcados, os escravos "ganhavam" um termo que lhes indicava a procedência, além do nome e sobrenome de seu proprietário, que poderia variar se houvesse a mudança de dono. O termo identificador da procedência (o nome da nação à qual o escravo ou liberto pertencia), porém, não mudava, mesmo após a alforria do escravo. ${ }^{27}$

No tocante ao nome que designava os cativos em geral, Mariza Soares mostrou que houve uma progressiva substituição do termo genérico "gentio da Guiné", ao qual todos os escravos eram submetidos, pelos nomes das nações. Essa substituição atendia melhor as exigências do tráfico e foi também utilizada por muito tempo como fator distintivo entre os diferentes comerciantes, alguns dos quais rivais entre si, como mostra Maria Inês Oliveira, ao discutir as disputas entre os traficantes baianos e os portugueses. ${ }^{28}$ Para Mariza Soares, a substituição se deve também ao fato de os escravos não mais serem classificados apenas de acordo com sua contribuição para a expansão do Cristianismo, mas pela relação do indivíduo com os conflitos existentes no continente africano e tendo em vista o porto em que teria sido embarcado. Outro reflexo

\footnotetext{
25 A designação de procedência no nome do escravo passou a constituir-se em prática efetiva ao longo do século XVIII. Para essa questão, ver: Mariza de Carvalho Soares, Devotos da cor: identidade étnica, religiosidade e escravidão no Rio de Janeiro, século XVIII, Rio de Janeiro: Civilização Brasileira, 2000, pp. 96-7.

26 Mariza de Carvalho Soares, "Mina, Angola e Guiné: nomes d'África no Rio de Janeiro setecentista”, Tempo, v. 3, n. 6 (1998), p. 73.

27 Soares, "Mina, Angola e Guiné", p. 76

28 Maria Inês Côrtes Oliveira, "Quem eram os negros da Guiné? A origem dos africanos na Bahia", Afro-Ásia, n. 19/20 (1997), pp. 37-73.
} 
que explica essa mudança diz respeito à forma como os portugueses se relacionavam com as populações africanas. ${ }^{29}$

Em alguns casos, o grupo étnico ao qual o escravo pertencia era levado em conta quando da identificação de sua nação, mas, grosso modo, o caráter definidor das nações no Brasil era mesmo o porto de embarque, a marca que garantia a procedência do "produto" vendido no "novo mundo". No entanto, isso não nos permite afirmar que, para os traficantes, o local de procedência em nada importava, uma vez que, nos livros de batismo, alguns indivíduos eram classificados como pertencentes a grupos minoritários (quissamã e loanda, por exemplo) em meio a vários outros majoritários, conforme lembra Mariza Soares..$^{30}$ A "nação" pode ser entendida como a categoria que classifica e distribui os escravos no tráfico atlântico. Esses indivíduos, agrupados em determinada "nação", eram de vários grupos étnicos em seu continente de origem. Diferenças podem ser encontradas na forma como as "nações" eram definidas em cada local, o que permite afirmar que a "nação mina" da Bahia, necessariamente não seria semelhante àquela de mesmo nome existente no Rio de Janeiro ou em Minas Gerais. ${ }^{31}$ As "nações" mina e angola também abrangiam uma grande diversidade de grupos étnicos, uma vez que existia uma grande quantidade de povos que pertenciam a inúmeros grupos, mas, ao serem embarcados nos portos do tráfico, ganhavam os nomes das nações com as quais trabalhavam os traficantes. ${ }^{32}$

Segundo Carlos Eugênio Soares, essas nações eram nomeadas tendo por base os portos e, na maioria das vezes, as "origens" étnicas não representavam uma informação válida, devendo mesmo, em determinados momentos, ser ocultadas, em se tratando de períodos de doenças em alguma região ou das qualidades que se atribuía à nação da qual se afirmava ser o escravo. Nesse sentido, os escravos teriam, grosso modo, duas "nações", uma de origem, à qual se referia para marcar sua diferença em relação aos seus companheiros de infortúnio, e a outra imposta pelo comércio de escravos, que o marcaria para sempre no "novo mundo".

\footnotetext{
Soares, "Mina, Angola e Guiné”, p. 78

Soares, "Mina, Angola e Guiné", p. 80.

Soares, "A 'nação' que se tem", p. 306

Soares, "Mina, Angola e Guiné”, p. 78.

84 Afro-Ásia, 49 (2014), 71-104
} 
Essa é também a conclusão de Mariza Soares, no já citado artigo intitulado "A 'nação' que se tem e a 'terra' de onde se vem". ${ }^{33}$

As diferenças existentes entre as nações nos estados não estão presas ao passado, uma vez que ainda hoje, em pleno século XXI, o que é definido como nagô em Pernambuco, necessariamente não corresponde à "nação" de mesmo nome nos estados de Alagoas, Paraíba e Sergipe. Mesmo nas "nações religiosas" da atualidade, predomina a diversidade, e inexistem relações que possam ser vistas como originadas de um único grupo étnico. ${ }^{34}$ Isso não impede que os praticantes religiosos de uma mesma nação não reivindiquem um escopo identitário em comum. Desse modo, consubstanciando a discussão historiográfica e a própria história de como as nações foram criadas no "novo mundo", há uma disputa em torno dos processos de identificação e etnicidade. Se, por um lado, para os senhores, era importante que as identidades escravas fossem as mais pulverizadas possíveis, evitando-se agrupamentos de sentido que pudessem levar a revoltas ou sedições, por outro, para os escravos, recriar o mundo perdido, as relações sociais e mesmo familiares era fundamental para que a vida fosse dotada de um mínimo de sentido em meio à escravidão. Assim, reafirmo, a discussão em torno das criações da "nação" é, acima de tudo, política.

Mariza Soares foi quem melhor definiu e interpretou o conceito de "nação", permitindo o entendimento dos modos como se deram as ressignificações dessas nações no âmbito do Brasil escravista pelos africanos escravos:

Em alguns casos, nações, grupos étnicos, reinos, vilas, regiões e grupos lingüísticos podem coincidir, em outros não. Os mahi são um bom exemplo dessa diversidade. No que pode parecer um jogo de palavras, a nação é o "lugar" de representação das novas identidades constituídas no Rio de Janeiro, tendo como base uma referência ao passado manifesta no uso de expressões como "terra de brutos", "quando vim de minha terra", "deus da sua terra". 35

\footnotetext{
33 Sobre esta questão, ver também: Carlos Eugênio Líbano Soares, A negregada instituição: os capoeiras no Rio de Janeiro, Rio de Janeiro: Prefeitura da Cidade do Rio de Janeiro, 1994, p. 37.

34 Sobre a diversidade entre os nagôs, ver: Dantas, Vovó nagô.

35 Soares, Devotos da cor, p. 319.
} 
A formulação "grupo de procedência" é uma importante construção conceitual que permite entender melhor o que se denominava "nação" no Brasil escravista. Nesse sentido, a "nação mina" é um "grupo de procedência" e não um grupo étnico, assim como as demais nações que, durante muito tempo, foram consideradas por alguns estudiosos como grupos efetivamente existentes no continente africano.

Essa questão está ainda presente nos debates antropológicos acerca das religiões de divindades e de entidades, bem como, ou principalmente, entre seus praticantes que afirmam, por uma questão identitária (dentre outras razões), a "origem africana de sua nação". Evidentemente, os membros dessas nações de candomblé não constituem grupos étnicos e, ao longo do século XIX, foram reunindo diversos outros indivíduos das mais variadas procedências. ${ }^{36}$ Devo destacar que existe ainda hoje uma forte tradição nos estudos de caráter histórico e antropológico das religiões de divindades e de entidades, em que a ideia de pureza e de superioridade de um grupo étnico (os nagôs) para outro (os bantos) predomina de modo arraigado.

Quanto ao conceito de "grupo de procedência", utilizado por Mariza Soares e outros estudiosos, há uma reflexão (e inspiração) no conceito de sistemas sociais abrangentes de Fredrik Barth, em que indivíduos de diferentes grupos étnicos participam, interagindo entre si. ${ }^{37}$ É importante salientar que, para Barth, "os grupos étnicos são categorias atributivas e identificadoras empregadas pelos próprios atores: consequentemente têm como característica organizar as interações entre as pessoas". ${ }^{38}$ Assim posto, nada mais correto do que manter a designação de maracatu-nação para os grupos em questão, pois assim se autodenominam e o fazem na medida em que essa designação confere sentido e significado às suas práticas e costumes.

No que diz respeito à relação entre identidade e o conceito de

\footnotetext{
36 Sobre a origem étnica dos grupos de candomblé na Bahia, ver: João José Reis e Eduardo Silva, Negociação e conflito: a resistência negra no Brasil escravista, São Paulo: Companhia das Letras, 1999; João José Reis, "Magia jeje na Bahia: a invasão do Calundu do Pasto de Cachoeira, 1795", Revista Brasileira de História, n. 16 (1988), pp. 57-81.

${ }^{37}$ Soares, "A 'nação' que se tem", p. 307; Bath, O guru, o iniciador, p. 26 e passim Barth, O guru, o iniciador, p. 26 e passim

${ }_{38}$ Barth, O guru, o iniciador, p. 27.

86 Afro-Ásia, 49 (2014), 71-104
} 
"nação", Mariza Soares estabeleceu a discussão mostrando que, mesmo tendo sido criada pelos traficantes e senhores de escravos, estes últimos tomaram para si e ressignificaram a ideia e os sentidos de "nação", refazendo as identidades a partir de um novo contexto. O trecho abaixo elucida com melhor propriedade essa questão:

Assim sendo, entendo que "nação", inicialmente uma identidade atribuída no âmbito do tráfico Atlântico, acaba sendo incorporada pelos grupos organizados no cativeiro e servindo como ponto de referência tanto para o reforço de antigas fronteiras étnicas e territoriais, como para o estabelecimento de novas configurações identitárias, sejam elas étnicas, ou não. ${ }^{39}$

Para Soares, a importância da terra de onde se vinha não deve ser desprezada, visto que até muitos ex-escravos, mesmo no fim de suas vidas, ao falarem sobre si, diziam de onde eram e informavam o nome de seus grupos e regiões de origem. Nina Rodrigues, ao entrevistar alguns desses remanescentes da escravidão, registrou com propriedade esse aspecto, destacando certo estranhamento pelo fato de que os minas do Maranhão não procediam do mesmo lugar que os minas baianos. Uma das suas conclusões a esse respeito é de que havia mais de um grupo étnico com o mesmo nome. ${ }^{40}$

Mariza Soares também indicou a existência da diversidade no seio da "nação mina", no Rio de Janeiro do século XVIII, mostrando que entre eles havia cabus, mahis e claras (ou charas). ${ }^{41}$ Maria Inês Oliveira, em seu trabalho sobre a origem dos africanos na Bahia, também discutiu os aspectos em torno da procedência dos escravos e dos equívocos que alguns estudos de historiadores e antropólogos nos legaram, por não terem levado em conta o fato de que a denominação do tráfico não possuía a mesma precisão dos informantes africanos. ${ }^{42} \mathrm{~A}$ importância das terras de onde se vinha e da nação que se tinha também pode ser atestada na larga aceitação e uso do termo "nagô" por parte dos diversos iorubanos de diferentes grupos que para o Brasil foram trazidos, os quais aceitavam

\footnotetext{
Soares, “A 'nação' que se tem”, p. 308.

Nina Rodrigues, Os africanos no Brasil, São Paulo: Nacional, 1932.

1 Soares, "A 'nação' que se tem", p. 317.

42 Oliveira, "Quem eram os negros da Guiné?", p. 60.
} 
tal termo como identificador genérico, mesmo que, em determinados momentos, expressassem suas diferenças no uso de complementos ao vocábulo nagô, tais como nagô-bá, nagô-jebu, nagô-gexa. ${ }^{43}$

Uma importante reflexão acerca dos estudos em torno da identidade dos africanos que viveram em cativeiro pode ser encontrada na recente obra de Luiz Nicolau Parés. Com base nos conceitos e estudos sobre etnicidade e identidade elaborados por Barth, afirma o autor que os africanos desenvolviam estratégias de identidade "nas quais os atores sociais, em função da sua avaliação da situação, utilizavam seus recursos de identidade de maneira estratégica, geralmente com o intuito de atingir algum objetivo". ${ }^{4}$ Para a questão em torno da identidade e das muitas possibilidades que os escravos possuíam para obter determinadas vantagens, Nicolau Parés utiliza uma metáfora baseada na comparação de identidades ao estilo das famosas bonecas russas encaixáveis umas às outras. Os africanos, segundo ele, podiam fazer uso de várias identidades, indo da categoria mais particular à mais genérica (savalu, jeje, mina, ou africano). Tal questão, acerca das muitas possibilidades em torno do uso das identidades, me fez pensar em outra metáfora, concebida por Lovejoy na comparação das identidades aos chapéus, possíveis de serem usados em diferentes momentos. Mahhommah Gardo Baquaqua foi um dos muitos africanos que dispôs do uso de muitas identidades, e as utilizou a seu favor, em diferentes ocasiões a que foi submetido no cativeiro. ${ }^{45}$

Sobre o processo de identificação, Nicolau Parés nos lembra que o fazer e refazer das identidades (entendendo-as como múltiplas e não essencializadas) pressupõe sempre a constituição do "outro", que pode ser um membro do mesmo grupo - e aqui a identidade se firma individualmente - além dos "outros" de outros grupos - para se referir às identidades grupais ou étnicas. Utilizando os conceitos barthianos acerca da etnicidade e identidade, Nicolau Parés enfatiza que é o contraste que demarca as fronteiras ou as relações baseadas na oposição. As diferenças,

43 Oliveira, "Quem eram os negros da Guiné?", p. 66.

${ }_{44}$ Luis Nicolau Parés, A formação do candomblé: história e ritual da nação jeje na Bahia, Campinas: Ed. da UNICAMP, 2006, p. 15.

45 Paul E. Lovejoy, "Identidade e a miragem da etnicidade. A jornada de Mahhomah Gardo Baquaqua para as Américas", Afro-Ásia, n. 27 (2002), pp. 9-39.

88 Afro-Ásia, 49 (2014), 71-104 
construídas por homens e mulheres vivendo em grupo, fazem e refazem suas identidades em um processo constante e dinâmico.

A identidade deve ser entendida como uma construção em um dado contexto e, nesse sentido, um nagô de Porto Alegre dificilmente será igual a um "irmão de nação" pernambucano. ${ }^{46}$ Partindo do conceito de "guarda-chuva étnico", formulado por João José Reis, uma tendência historiográfica procura mostrar o fato de que as nações foram mesmo usadas como forma de identidade mais ampla, na qual diversos grupos compunham sua identidade. ${ }^{47}$ Nessa perspectiva, as nações devem ser vistas como construções transnacionais, formadas no contexto urbano, e não apenas a partir de heranças africanas essencializadas. ${ }^{48}$

As identidades eram constituídas por muitos elementos, que iam além do simples fato de terem os escravos sido embarcados em um mesmo porto, ou de serem de um suposto grupo étnico em comum. Tatuagens, marcas diversas (os ferros que marcavam os escravos), forma de se vestir e cortes de cabelos eram alguns dos sinais diacríticos utilizados pelos escravos no processo de invenção das identidades. A produção dos sinais, a exemplo dos cortes de cabelo, foi fundamental para a criação e conformação das nações, além, sobretudo, de seu reconhecimento.

Os jejes possuíam múltiplas identidades, apesar da aceitação e do uso do termo generalizante - jeje — que ainda hoje serve como sinal diferenciador daqueles que se consideram herdeiros desse legado e que se agrupam nos terreiros de candomblé dessa nação. Nina Rodrigues revelou existirem diferenças entre os jejes baianos e os brasileiros de um modo geral. Maria Inês Oliveira, em artigo já citado, afirmou que eles não se viam como uma unidade cultural, existindo, em determinados momentos, fortes conflitos resultantes das diferenças políticas do continente de origem. ${ }^{49}$

A maior parte dessas nações recriadas vão desaparecendo ao lon-

\footnotetext{
46 Juliana Barreto Farias, Carlos Eugênio Líbano Soares e Flávio dos Santos Gomes, No labirinto das nações: africanos e identidades no Rio de Janeiro, século XIX, Rio de Janeiro: Arquivo Nacional, 2005, p. 51.

47 Farias, Soares e Gomes, No labirinto das nações.

48 Farias, Soares e Gomes, No labirinto das nações, p. 50

49 Oliveira, "Quem eram os negros da Guiné?", p. 72.
} 
go da segunda metade do século XIX, ou melhor, deixam de ser usadas como autorreferência étnica ou identitária, na medida em que o tráfico de escravos termina e se consolida a grande designação de "africanos", para se referir aos escravos oriundos do continente, em oposição aos escravos nascidos no Brasil. No entanto, a África, de um modo genérico, continua a ser uma referência identitária. Manuela Carneiro da Cunha, em seu estudo Negros estrangeiros: os escravos libertos e sua volta à África, brilhantemente demonstra como esses indivíduos, quando voltam para a África, não são mais reconhecidos como pertencentes aos grupos étnicos de que se originaram, por terem perdido relações de parentesco, dentre outras questões. Aqueles que foram para a África em busca de seu lar são considerados estrangeiros, brasileiros. ${ }^{50}$

Stuart Hall, em seu artigo "Identidade cultural e diáspora", lembra o quão importante é, para o processo de produção de identidades culturais e dos movimentos negros, essa busca de uma identidade essencial, que é definida por Franz Fanon como uma "busca profunda", uma identidade em que a África é central porque se baseia não numa arqueologia, em desenterrar as continuidades ocultas, os "africanismos" ainda presentes nas manifestações culturais, mas em recontar o passado. Trata-se de uma redescoberta imaginativa, de uma "unidade subjacente do povo negro, que a colonização e a escravidão dispersaram com a diáspora africana." ${ }^{51}$ Tal identidade essencializada busca "impor uma coerência imaginária à experiência da dispersão e fragmentação, que é a história de todas as diásporas forçadas". Fazem-no representando ou figurando a África como mãe de todas essas civilizações diferentes. O triângulo, afinal de contas, está centrado na África. África é o nome do termo ausente, a grande aporia que jaz no centro de nossa identidade cultural e dá-lhe um sentido que ela, até recentemente, não tinha. Ninguém que contemple essas imagens textuais agora, à luz da história do tráfico, escravidão e migração, deixará de entender como o abismo da separação, a "perda da identidade", [...] "só começa a ser superado quando essas conexões esquecidas são, mais

\footnotetext{
50 Manuela Carneiro da Cunha, Negros estrangeiros: os escravos libertos e sua volta à África, São Paulo: Brasiliense, 1985.

51 Stuart Hall, "Identidade cultural e diáspora", Revista do Patrimônio Histórico e Artístico Nacional, n. 24 (1996), pp. 68-75.

90 Afro-Ásia, 49 (2014), 71-104
} 
uma vez, reestabelecidas". ${ }^{52}$ Essa África imaginária permite, em outras palavras, cruzar o abismo produzido pelo tráfico. Essa África ainda é fundamental para a constituição das identidades dos maracatus-nação na atualidade, pois constitui o mito de origem.

\section{Os maracatus: em busca de sua história}

Ao me deparar com um debate em torno das nações constituídas durante o tráfico de escravos, a primeira pergunta que me fiz foi sobre a relação entre as mesmas e os maracatus. É possível transpor esse debate colocando os maracatus-nação como continuadores das antigas nações que porventura existiram em Pernambuco? É preciso, a meu ver, pensar a forma como a ideia de nação vai se constituindo para os maracatus no seu fazer histórico em Pernambuco, em sua relação própria com as religiões. Esses liames entre os xangôs, as juremas e os maracatus não são naturais, mas uma construção feita por homens e mulheres ao longo dos anos e em meio a uma infinidade de questões relacionadas com contextos diversos. ${ }^{53}$

Os maracatuzeiros tomaram os terreiros como locais de possibilidades, e os praticantes das religiões de divindades e de entidades viram a recíproca nos maracatus. Isso em se tratando de tomarmos como dado o fato de que as separações existiram e que os praticantes dessas religiões não são os mesmos maracatuzeiros nos momentos de descontração, ou que estes não são aqueles nos períodos de dificuldades diversas. Se há, na atualidade, liames entre as religiões de divindades e de entidades com os maracatus-nação, esses também ocorrem no seio de outras manifestações culturais, e isso não deve ser tomado como um dado da natureza, ou que, desde os seus primórdios, tenha havido laços envolvendo ambas as práticas. Os maracatus possuem uma historicidade, e o processo de construção das relações com as religiões de divindades e de entidades possui diversas lacunas a serem preenchidas. Sequer sabemos, por exemplo, as razões que nortearam homens e mulheres a se reunirem em determinados grupos denominados maracatus, e os motivos que fizeram

\footnotetext{
${ }_{52}$ Hall, "Identidade cultural e diáspora", p. 69.

53 Guillen, "Xangôs e maracatus".
} 
com que existissem por tanto tempo, por mais que fossem reprimidos e malvistos. Se, atualmente, os maracatus possuem grande aceitação, época houve em que eram denunciados como práticas incivilizadas e estúpidas, indignas de existirem em um Brasil que se queria branco, europeu e civilizado.

Também não se sabe como eram esses maracatus do final do século XIX, se eram chamados efetivamente de nações bem como quais os sentidos que estavam por trás desse termo. Sabe-se que havia vários sentidos para a palavra "maracatu", mas não encontrei evidências documentais que me permitam afirmar algo sobre os sentidos da palavra "nação" entre os maracatuzeiros do final do século XIX e dos trinta primeiros anos do século XX, bem como se os maracatuzeiros utilizavam a palavra com o mesmo sentido em que era empregado nas religiões de divindades e de entidades, o que não ocorre na atualidade. Nos debates travados sobre as origens e os significados da palavra "maracatu", ressalta-se a polissemia do termo, além da evidente dificuldade em definir seu campo semântico.

Importa que a palavra tenha seus usos - e práticas — que se tornam historicamente perceptíveis na segunda metade do século XIX, quando também nasceu Dona Santa, famosa rainha do Maracatu Nação Elefante. Até então, e concomitantemente ainda durante algumas décadas, o termo corriqueiro para se referir às festas de negros em que música e dança se associavam era "batuque".${ }^{54}$ No Recife do período em questão, batuques e maracatus conviviam no vocabulário cotidiano, visíveis nos jornais como sinônimos, sem que fosse possível demarcar nítidas diferenças e fronteiras. Não temos como entrevistar os maracatuzeiros desse período, e tampouco existem documentos produzidos por eles ou pelos órgãos de repressão (pelo menos, eu ainda não os encontrei), restando-me alguns indícios nos jornais que registraram feroz oposição à prática do maracatu. Esse processo se torna perceptível ao final do século, quando os maracatus aparecem nos carnavais, como "brincadeira" ou grupo próprio.

\footnotetext{
${ }_{54}$ Martha Abreu, O Império do Divino: festas religiosas e cultura popular no Rio de Janeiro, 1830-1900, Rio de Janeiro: Nova Fronteira, 1999, especialmente páginas 287-90; João José Reis, "Tambores e temores. A festa negra na Bahia na primeira metade do século XIX", in Maria Clementina Pereira da Cunha (org.), Carnavais e outras f(r)estas (Campinas: Ed. Unicamp, 2005).

92 Afro-Ásia, 49 (2014), 71-104
} 
Reprimidos, como muitas festas e batuques por todo o Brasil, o maracatu encontraria no carnaval espaço legítimo para transitar nas ruas, ocupar o espaço público. Ganhar visibilidade e legitimidade social podem ser algumas das razões que levaram os maracatuzeiros a ocupar as ruas durante o carnaval..$^{55}$ Ainda que esses grupos de maracatu não passassem de uma dezena - ou pelo menos assim deduzo, tomando como base aqueles que desfilavam pelo centro da cidade e eram registrados pelos jornais —, já se firmavam como "reminiscência africana" a partir da célebre descrição feita por Pereira da Costa em "Folk-lore pernambucano", em que estão dadas sua origem africana, características próprias, tais como o cortejo real e a orquestra de percussão, classificando-a como uma manifestação folclórica. ${ }^{56}$

Adentramos o século XX com parcos registros que nos possibilitem pensar diferenças, divergências ou mesmo mudanças em relação ao modelo proposto por Pereira da Costa. O maracatu aparece brevemente nas colunas carnavalescas, que tão somente registram os grupos que desfilavam em frente à sede dos jornais, ou aqueles que provocaram brigas e arruaças. Lendo as colunas policiais, observo pequenos detalhes desses grupos, rivalidades e brigas que pontuavam as notícias carnavalescas. ${ }^{57}$ Nas memórias de jornalistas e cronistas que viveram e escreveram nestas primeiras décadas, aparecem, ainda que muito raramente, alguns

\footnotetext{
55 Sobre maracatus e batuques no século XIX, ver: Clarissa Nunes Maia, Sambas, batuques, vozerias e farsas públicas: o controle social sobre os escravos em Pernambuco no século XIX (1850-1888), São Paulo: Annablume, 2008; Marcelo Mac Cord, O Rosário de D. Antônio: irmandades negras, alianças e conflitos na história social do Recife, 1848-1872, Recife: FAPESP/Editora Universitária UFPE, 2005. Sobre a migração dos maracatus para o carnaval, ver: Rita de Cássia Barbosa de Araújo, "Festas públicas e carnavais: o negro e a cultura popular em Pernambuco", in Luiz Sávio de Almeida, Otávio Cabral e Zezito Araújo (orgs.), O negro e a construção do carnaval no Nordeste (Maceió: EDUFAL, 1996). Para o carnaval carioca, ver: Maria Clementina Pereira da Cunha, Ecos da folia: uma história social do carnaval carioca entre 1880-1920, São Paulo: Companhia das Letras, 2001; Rachel Soihet, A subversão pelo riso, Rio de Janeiro: FGV, 1998. Para o carnaval na Bahia, ver: Peter Fry, Sérgio Carrara e Ana Luiza Martins Costa, "Negros e brancos no carnaval da velha república", in João José Reis (org.), Escravidão e invenção da liberdade: estudo sobre o negro no Brasil (São Paulo: Brasiliense, 1988).

${ }_{56}$ Pereira da Costa, "Folk-lore pernambucano. Subsídios à história da poesia popular em Pernambuco", Revista do Instituto Histórico e Geográfico Brasileiro, tomo LXX, parte II (1908). Sobre Pereira da Costa e os maracatus, ver: Ivaldo Marciano de França Lima, "Práticas e representações em choque: o lugar social dos maracatus na cidade do Recife, nos anos de 1890-1930", Clio, Série História do Nordeste, v. 1, n. 21 (2003), pp. 85-106.

57 O Jornal Pequeno, Recife, de 12 de fevereiro de 1902, noticia uma dessas brigas.
} 
maracatuzeiros, a exemplo de Adama, descrito por Oscar Melo como valente capoeirista. ${ }^{58}$

Desde o final do XIX, intensificando-se na década de 1920, a maior fiscalização por parte do aparelho policial e um enrijecimento das normas oficiais, promovido pelo Estado Republicano, fizeram com que práticas culturais como os maracatus, pastoris e outras fossem objeto de intervenção pública, algumas proibidas pelos códigos de postura municipal, tornando-se passíveis de criminalização e perseguição policial, a exemplo dos batuques ou cerimônias das religiões de divindades e de entidades. ${ }^{59}$

Não só maracatus como também blocos e troças carnavalescas, pastoris, circos, fandangos, além de pensões e casas de cômodo, bares, clubes esportivos e até barraquinhas de festas religiosas eram fiscalizados periodicamente por "peritos" e "censores" indicados pelo Inspetor de Polícia, que, mediante o pagamento de valores previamente arbitrados, expediam as licenças de funcionamento. Respaldados no poder que os discursos de cunho sanitarista lhes conferiam, os fiscais aprovavam ou proibiam o funcionamento das diversões e práticas culturais, fixando dia, horário de funcionamento e exigindo o cumprimento das normas instituídas com base nos padrões estéticos e morais ditados pela elite. Tais medidas, calcadas nos ideais em voga nessa fase (civilização, progresso, higienismo e moralização da sociedade), apesar de aumentarem a repressão sobre os divertimentos e práticas culturais populares e contribuírem para a diminuição do número de grupos de maracatus organizados, não obstante, não conseguiram controlar ou extinguir em definitivo as manifestações da cultura "dita popular", que vão elaborar outras estratégias para fugir das perseguições policiais.

Nos anos finais do século XIX e adentrando as primeiras décadas do século XX, assistimos no Recife um formidável teatro de controle

\footnotetext{
58 Oscar Melo, Recife sangrento, Recife: Edição do Autor, 1953, especialmente as páginas 139-42. Sobre Adama, ver: Ivaldo Marciano de França Lima, “Adama e Nascimento Grande: valentes do Recife da Primeira República”, Cadernos de Estudos Sociais, v. 22 (2006), pp. 49-61; Israel Ozanan de Souza Cunha, "Capoeira e capoeiras entre a Guarda Negra e a Educação Física no Recife" (Dissertação de Mestrado em História, Universidade Federal de Pernambuco, 2013).

59 Maia, Sambas, batuques, vozerias; Sylvia Costa Couceiro, "Artes de viver a cidade. Conflitos e convivências nos espaços de diversão e prazer do Recife nos anos 1920" (Tese de Doutorado em História, Universidade Federal de Pernambuco, 2003).
} 
social em que as ruas da cidade e diversos tipos de divertimentos populares se transformam em cenário para as mais dramáticas ocasiões para a encenação de confrontos e conflitos. O carnaval se encontra no epicentro dessa questão, e é em torno de sua normatização — visando a controlar a "turba incivilizada" - que giram os debates. ${ }^{60} \mathrm{O}$ carnaval vai se constituindo como um palco em que blocos, troças, maracatus e caboclinhos são instados a desfilar ordeira e civilizadamente em espaços determinados da cidade, seguindo traçados pré-estabelecidos, e sendo posteriormente agraciados com prêmios e taças, enquanto a população é instada a comprovar pelo voto aqueles que melhor seguiam as regras. ${ }^{61}$

Em 1935, criou-se a Federação Carnavalesca que, durante o Estado Novo ou o governo de Agamenon Magalhães, consolidou esse controle. A tal ponto que, em 1947, nas páginas dos jornais da cidade do Recife, acompanhamos o debate sobre o "excesso" de controle que a Federação exercia sobre a folia carnavalesca. Gilberto Freyre já podia se opor à Federação em favor de um carnaval "espontâneo" e popular, raiz da "autêntica" cultura pernambucana, pois então não mais os capoeiras acompanhavam as "brincadeiras" provocando arruaças, e a violência se expressava em outros contextos simbólicos. ${ }^{62}$

Muito ainda há que ser feito em torno da história dos maracatus, mas, no fundamental, é perceptível a constituição de identidades em torno de alguns grupos que conseguem sobreviver à repressão e aos duros momentos do Estado Novo. Se alguns autores, a exemplo de Katarina Real,

${ }^{60}$ Rita de Cássia Barbosa de Araújo, Festas: máscaras do tempo, Recife: Fundação de Cultura da Cidade do Recife, 1996, especialmente cap. IV, "No frevedouro da República". Sobre a noção de teatro, ver: E. P. Thompson, As peculiaridades dos ingleses e outros artigos, Campinas: Ed. da UNICAMP, 2001, p. 241 e passim.

${ }_{61}$ Os concursos carnavalescos começam a ocorrer nos dez primeiros anos do século XX com o incentivo dos jornais e empresas privadas. Eis alguns jornais que noticiaram os concursos carnavalescos do período: Jornal do Recife, 21 de fevereiro de 1909, p. 1; Jornal do Recife, 23 de fevereiro de 1911, p. 2. Nos anos 1930, antes da criação da Federação Carnavalesca, assiste-se ainda a considerável número de certames, todos promovidos por jornais e empresas privadas: Jornal do Recife, 24 de fevereiro de 1933, p. 2. Diversos outros concursos aconteceram nesses anos, a exemplo da "Taça A. Souza de Mello", Jornal do Recife, 23 de fevereiro de 1933, p. 2 e "Taça Silgo", Jornal do Recife, 25 de fevereiro de 1933, p. 5.

62 Francisco Mateus Carvalho Vidal, "A fresta do Estado e o brinquedo para os populares: histórias da Federação Carnavalesca Pernambucana” (Dissertação de Mestrado em História, Universidade Federal de Pernambuco, 2010). Para esse debate em 1947, ver: Gilberto Freyre, "Carnaval do povo. Carnaval de Federação", Diário de Pernambuco, 08 de janeiro de 1947. O debate se estendeu por vários dias. 
afirmam ter sido esse o momento em que os laços envolvendo os terreiros e os maracatus se estreitaram, faz-se necessário afirmar que a ausência de maiores informações a respeito dos trinta primeiros anos do século XX me deixa atordoado o suficiente para discorrer sobre essa questão com fortes certezas. ${ }^{63} \mathrm{O}$ certo é que os maracatuzeiros constituíram laços com os terreiros, e isso foi fundamental para que a ideia de "nação" ganhasse força e terreno. Apesar de que, como afirmo na introdução deste trabalho, "nação" também é um termo usado por outras manifestações para designar um grupo específico, sem que necessariamente tenha relação com as religiões de divindades e de entidades.

A ideia de "nação", para os maracatus, é uma construção ressignificada, e infelizmente não existem vestígios que possam nos levar a algumas pistas sobre os sentidos das nações de maracatu até os anos 1930 do século passado. O que entendo por "nação", portanto, é uma construção identitária bastante atual, com novos significados agregados, sobretudo o aspecto religioso, que nos dias de hoje é imprescindível e definidor de um maracatu que se queira legítimo e autêntico entre seus congêneres. Em diversos depoimentos tomados com os fundadores do Maracatu Cambinda Estrela, a palavra "nação" aparece com recorrência, demonstrando a coloquialidade com que a relação "maracatu" e "nação" estava estabelecida nos anos 1930. Dona Leinha, ao se lembrar de diversas histórias que envolviam seu pai e o Cambinda Estrela, utiliza a palavra "nação" como sinônimo de maracatu: "colocar a nação na rua"; "quem saiu com a nação", etc. No entanto, um dado complicador precisa ficar explícito: o Cambinda Estrela era um maracatu de orquestra e não um maracatu-nação! Assim, nação e maracatu de baque virado não são associações naturais, mas historicamente construídas! E os maracatus de orquestra continuam se autodenominando de nação, e não há entre essa manifestação nenhuma relação explícita com a religião dos orixás, ao menos diante das leituras que venho fazendo sobre esse assunto. ${ }^{64}$

63 Katarina Real, O folclore no carnaval do Recife, Recife: Fundação Joaquim Nabuco/Massangana, 1990.

64 Sobre os maracatus rurais, ver: Roberto Benjamin, "Maracatus rurais de Pernambuco", in Américo Pellegrini Filho (org.), Antologia de folclore brasileiro (São Paulo: Edart, 1982), pp. 199-212; Mariana Cunha Mesquita do Nascimento, João, Manoel, Maciel Salustiano: três gerações de artistas populares recriando os folguedos de Pernambuco, Recife: Reviva, 2005.

96 Afro-Ásia, 49 (2014), 71-104 
Há também a ideia muito forte entre os populares de que um maracatu-nação só possui vínculos com a religião dos orixás, apontando para o discurso da "pureza africana" existente no modelo nagô, daí por que os maracatus do tipo orquestra são empurrados para uma suposta ligação com a jurema. Guerra-Peixe fez afirmações nessa mesma perspectiva, corroborando para que se fortalecessem, dada a grande representatividade que a obra Maracatus do Recife tomou nos anos 1980, os laços entre o maracatu-nação "africano" e "puro", com o terreiro de xangô nagô "autêntico". Escreveu Guerra-Peixe sobre essa questão:

É oportuno realçar o que nos esclareceram os informantes de vários grupos: a gente do maracatu tradicional — nagô, como dizem, no sentido de africano - é constituída, na maioria, por iniciados nos xangôs; a que prefere o maracatu-de-orquestra, tende para o catimbó, culto popular de características eminentemente nacionais. Parece que há procedência nas informações, pois nos cânticos do maracatu-de-orquestra é constante o aparecimento de vocábulos como aldeia, caboclo, jurema e outros todos refletindo identificações que acusam a preferência religiosa dos seus participantes. ${ }^{65}$

Entretanto, faz-se necessário deixar claro que a jurema nunca deixou de fazer parte do universo mítico-religioso dessas nações de maracatu, por mais que estivesse invisibilizada. As duas rainhas de maracatu-nação mais representativas no imaginário dos maracatuzeiros da atualidade, Dona Santa e Maria Madalena, eram juremeiras e não escondiam de ninguém a prática dessa religião, assim como os vínculos de seus maracatus com a mesma. Também Luiz de França, outro grande

\footnotetext{
65 Guerra-Peixe, Maracatus do Recife, p. 23. Tal questão influenciou sobremaneira os estudiosos que lhe seguiram nas pesquisas sobre os maracatus-nação, e a relação estabelecida por Guerra-Peixe sequer foi questionada e ainda hoje é aceita como tal, inclusive entre alguns maracatuzeiros que afirmam terem vínculos apenas com a religião dos orixás, negando qualquer tipo de vínculo com a jurema. Sobre a questão da "pureza africana e nagô" nas religiões de divindades e de entidades, ver: Dantas, Vovó nagô; Roberto Motta, “A invenção da África: Roger Bastide, Édison Carneiro e os conceitos de memória coletiva e pureza nagô", in Tânia Lima (org.), Sincretismo religioso: o ritual afro. Anais do IV Congresso Afro-Brasileiro (Recife: Massangana/Fundaj, 1996), pp. 2432; Roberto Motta, "Antropologia, pensamento, dominação e sincretismo", in Sylvana Brandão (org.), História das religiões no Brasil, v. 3 (Recife: Ed. da UFPE, 2004), pp. 487-523. Sobre a questão da dominação iorubá (nagô), ver: Lívio Sansone, "Da África ao afro: uso e abuso da África entre os intelectuais e na cultura popular brasileira durante o século XX", Afro-Ásia, n. 27 (2002), pp. 249-69.
} 
maracatuzeiro, tido como ícone de legitimidade entre os seus pares, não escondia o fato de que no maracatu existem "os senhores mestres", forma pela qual a jurema também é conhecida em Pernambuco.

Nesse sentido, existem muitas lacunas a serem preenchidas acerca dos significados que a palavra "nação" tomou para os maracatuzeiros ao longo do tempo. O certo é que, na atualidade, tal termo tornou-se um dos aspectos mais fortes na constituição das identidades e dos perfis exibidos pelos maracatus-nação para se diferenciarem dos "estilizados" ou "grupos percussivos". Esta questão, a construção dos perfis e das diferenças, pode ser mais bem pensada à luz das discussões encetadas por Fredrik Barth, em seus estudos sobre as fronteiras existentes entre os grupos étnicos. Para Barth:

As fronteiras étnicas permanecem apesar do fluxo de pessoas que a atravessam. Em outras palavras, as distinções entre categorias étnicas não dependem da ausência de mobilidade, contato e informação, mas implicam efetivamente processos de exclusão e de incorporação, através dos quais, apesar das mudanças de participação e pertencimento ao longo das histórias de vida individuais, essas distinções são mantidas. ${ }^{66}$

Tendo essa assertiva em nosso horizonte, podemos nos interrogar: quais as fronteiras que existem entre os maracatus-nação e os grupos percussivos na atualidade?

\section{Nas fronteiras dos maracatus: a(s) identidade(s) em questão}

Não creio ser possível afirmar a existência de uma identidade de caráter étnico nos maracatus-nação. Ainda que sejam formados em grande parte por negros e negras, o que ocorre é muito mais um compartilhamento de algumas práticas, ideias e principalmente sentidos, mas nunca uma identidade de caráter étnico, uma vez que os maracatus-nação, apesar de compartilharem identidades, não se constituem em grupos de parentesco, ou comunidades fechadas. No tocante à questão da negritude,

${ }_{66}$ Barth, O guru, o iniciador, p. 26.

98 Afro-Ásia, 49 (2014), 71-104 
majoritária nos maracatus-nação, ocorre, a meu ver, o que Lívio Sansone denominou negritude sem etnicidade, uma vez que não há a valorização de sinais diacríticos ou de traços particulares a uma identidade que diferencie os maracatuzeiros dos demais indivíduos que convivem na mesma sociedade. ${ }^{67}$

Há nos maracatus um compartilhamento de práticas, modos de fazer, de viver e de ver o mundo, sobretudo pelo fato de que a maior parte das pessoas que convivem nos maracatus-nação residem próximas, e essa é a principal diferença entre os maracatus-nação e os grupos percussivos. Não existem apenas laços religiosos entre os integrantes de um maracatu-nação, mas principalmente o compartilhamento de práticas, o que lhes confere, em muitos casos, uma espécie de ethos, que não existe em um grupo que se reúne para tocar, cantar e se divertir nos finais de semana. Tomando por empréstimo a noção de permanência das fronteiras étnicas de Barth, de que elas independem da ausência de mobilidade e contato, para entendermos os maracatus-nação é necessário levar em conta seu processo de formação histórica. Cada maracatu tem um processo próprio de formação dos grupos, e consequentemente da identidade grupal.

Não posso homogeneizar o processo de formação dos grupos de maracatus, e, nesse sentido, as discussões sobre as possibilidades que o uso da biografia tem apontado para os historiadores vêm sendo fundamentais para pensar a ação singular de alguns líderes maracatuzeiros. Dona Santa, no Elefante, Luiz de França, no Leão Coroado, Madalena e Rosinete, no Elefante dos anos 1990, como pensar essas nações sem levar em consideração as ações desses indivíduos, suas capacidades de elaborarem estratégias de inserção social, bem como as disputas por espaços e visibilidade que estabeleceram entre si? Giovanni Levi alerta que uma nova abordagem das estruturas sociais, que leva em consideração as solidariedades sociais:

[...] nos induz a apresentar de modo menos esquemático os mecanismos pelos quais se constituem redes de relações, estratos e grupos sociais. A medida de sua solidariedade e a análise da maneira pela qual se fazem e desfazem as configurações sociais levantam uma questão essencial:

${ }^{67}$ Lívio Sansone, Negritude sem etnicidade, Rio de Janeiro: Pallas; Salvador: EdUFBA, 2004. 
como os indivíduos se definem (conscientemente ou não) em relação ao grupo ou se reconhecem numa classe? ${ }^{68}$

Devo afirmar que o compartilhamento de práticas e sentidos é, em muitos casos, anterior à constituição do maracatu, mas contribui sobremaneira para retroalimentar as mesmas práticas. Se determinado grupo de pessoas, integrantes de um mesmo terreiro, com laços pessoais diversos e residentes em uma determinada comunidade fazem a opção pela construção ou reativação de um maracatu, então fica claro o entendimento de como esse se serviu dos laços identitários que o antecedem. Porém, o decorrer do processo, bem como da própria vida, contribuirá para que o maracatu propicie o reforço desses laços, influindo em modificações, em alguns casos, e permanências em outros. O que define a fronteira entre o grupo percussivo (não nação) e o maracatu-nação são os laços comunitários presentes neste último, tanto nos modos de fazer e os sentidos, do que no pertencimento a uma determinada religião. Seja ela de divindades ou de entidades, pois o fato de um grupo de maracatu percussivo constituir laços com um terreiro não irá lhe propiciar sentidos em comum.

As observações que fiz em alguns grupos percussivos cariocas me permitiram estabelecer algumas conclusões. A maior motivação existente entre os integrantes dos grupos à época existentes (2006 e 2007) estavam relacionadas com a diversão, o prazer e a higiene mental. Esses grupos eram integrados por médicos, psicólogos, professores, dentistas, estudantes universitários, dentre outros. Não pude perceber um compartilhamento de sentidos, ideias e práticas, tampouco constatei a existência de laços que não fossem além do final de semana em que se encontravam para tocar um instrumento nas festas ou espaços em que ensaiavam. Nos maracatus-nação, é comum encontrar homens e mulheres que residem em uma mesma comunidade, convivendo com os mesmos problemas e constituindo identidades semelhantes. Importa para essa questão, entretanto, pensar nas diferenças e como elas propiciam práticas distintas no interior dos grupos percussivos e dos maracatus-nação.

\footnotetext{
68 Giovanni Levi, "Usos da biografia”, in Marieta de Moraes Ferreira e Janaína Amado (orgs.), Usos \& abusos da História oral (Rio de Janeiro: Fundação Getúlio Vargas, 1996), p. 173. Ver ainda: Pierre Bourdieu, “A ilusão biográfica”, in Ferreira e Amado (orgs.), Usos \& abusos; Sabina Loriga, "A biografia como problema”, in Revel (org.), Jogos de escala.
} 
O compartilhamento de práticas também ocorre nos terreiros em que seus integrantes residem em uma mesma comunidade, corroborando a ideia de nação religiosa e de uma comunidade de sentidos semelhante à visão proposta por Turner, ao discutir seus conceitos de communitas e de liminaridade.$^{69}$ Estou tratando não de uma comunidade de sentidos na exata acepção do termo formulado por Turner, mas na perspectiva de compreender os maracatus-nação como construções feitas por pessoas que possuem muitos laços entre si, dos quais o compartilhamento de práticas e o fato de residirem próximos uns dos outros lhes permite maiores possibilidades de conformarem uma "nação", mesmo que esta tenha enormes diferenças das nações formadas no âmbito do tráfico de escravos do período escravagista.

Esse compartilhamento de práticas e sentidos, no entanto, não impede que existam trânsitos entre os integrantes dos maracatus-nação. Não há rigidez ou imobilidade no pertencimento a um determinado maracatu-nação, apesar de que este não existe pelas mesmas razões dos grupos percussivos. O núcleo central dos maracatus-nação da atualidade são as comunidades, principalmente aquelas em que seus moradores possuem práticas e costumes compartilhados. Refiro-me ao fato de que as comunidades em que os maracatus estão inseridos possuem maiores laços entre as pessoas, não sendo apenas o local da moradia, mas principalmente o ponto em que os maracatuzeiros reconhecem como sendo seu e fundamentalmente possui identificação com as pessoas e os laços existentes entre elas.

\section{Algumas conclusões}

Uma das conclusões possíveis de serem apontadas neste trabalho diz respeito às grandes diferenças existentes entre o termo "nação", que se construiu ao longo do tráfico e da escravidão no Brasil, e a que nomeia os grupos "tradicionais" de maracatus na cidade do Recife, sobretudo após os anos 1930. A ideia de "nação" existente nesses grupos está presente nos

\footnotetext{
${ }^{69}$ Victor W. Turner, O processo ritual: estrutura e anti-estrutura, Petrópolis: Vozes, 1974. Ver especialmente os capítulos 3 e 4 .
} 
maracatuzeiros que exibem símbolos, coroas e soberanos, mostrando que se trata de grupos com maiores afinidades entre si do que na sociedade como um todo. Faz-se necessário, no entanto, perceber que essa ideia de nação, ressignificada ao longo do século XX, não imputa a esses grupos a imobilidade no pertencimento ou rigidez no ingresso. Os limites entre as nações estão presentes nos contrastes em que os seus discursos são construídos, notadamente na forma como esses grupos se relacionam com os poderes públicos e as comunidades em que estão inseridos, nas cores que escolhem, nas toadas que cantam e nos instrumentos que os batuqueiros utilizam. Cada maracatu-nação possui uma forma de tocar seus instrumentos e, principalmente, um conjunto de estratégias levadas a efeito pelos seus principais articuladores.

Se, entre um maracatu-nação e um grupo percussivo, existe uma relação de alteridade, em que o pertencimento a uma comunidade é a marca fundamental, entre as nações de maracatu as escolhas quotidianas separam-nas umas das outras, fazendo com que seus integrantes a cada dia reforcem os vínculos com o grupo, retroalimentando os sentidos compartilhados presentes entre os membros. Alguns maracatus-nação escolhem o discurso da tradição como principal estratégia de inserção social e busca da legitimidade, ao passo que outros optam pelo diálogo com o mercado e a indústria cultural como melhor forma de manter seus espaços. Em ambos os tipos, existem estratégias que não podem jamais ser vistas como simples atos folclorizados ou destituídos de sentido e lógica.

Os tipos de toques, as formas de cantar, as letras das toadas, os vínculos religiosos e o modo pelos quais são tecidos, as conveniências propiciadas aos integrantes da nação, o prazer que advém em fazer algo com que se identificam, e os discursos identitários construídos pelo grupo, dentre outras questões, fazem as fronteiras entre os diferentes maracatus-nação. As escolhas de cada grupo e as regras estabelecidas por eles impõem limites suficientes para que o trânsito existente entre seus integrantes ocorra numa proporção pequena, quando comparado com o número de pessoas que permanecem. $\mathrm{O}$ que faz um maracatu-nação ser uma nação é, antes de tudo, o compartilhamento tenso, constante e dinâmico de um sem número de modos de fazer, de sentir e de compreender que tecem liames entre as pessoas, tornando-as parte de um 
grupo, levando-as a se assumirem como maracatuzeiros e constituindo uma identidade na qual estão presentes valores e sentimentos religiosos peculiares, muitas vezes existentes apenas naquele terreiro, entre as pessoas daquela comunidade que fazem determinado maracatu.

Esse fazer dinâmico e tenso é objeto de algumas questões aqui colocadas, mas que não serão facilmente resolvidas, pois estou convicto de que, muito mais do que ter categorias de análise prontas e adequar os objetos aos nossos propósitos, o trabalho do historiador consiste em observar como essas categorias se constituem historicamente, como são usadas pelos atores sociais e como muitas vezes são apropriadas pelos intelectuais, principalmente das ciências humanas. E para essa questão é fundamental o diálogo da História com a Antropologia, a partir do uso de categorias conceituais por parte de ambas.

Importa para agora, no entanto, pensar como os maracatus-nação adquirem novas características e ressignificam suas identidades. Pensar como se impuseram em diferentes contextos, nesse sentido, é buscar o entendimento das lógicas que teceram, em meio a diferentes identidades possíveis de serem estabelecidas, e constituíram-se em grupos de espetáculo, adentrando o mercado simbólico do carnaval pernambucano, obtendo legitimidade e espaços numa sociedade fortemente disputada por outras manifestações da cultura negra. Eis a complexidade que permeia os maracatus-nação, suas diferenças entre si e os grupos percussivos.

Artigo recebido em 18 de abril de 2013 e aprovado em 21 de junho de 2013 


\section{Resumo}

Este artigo objetiva discutir as diferenças entre os maracatus-nação e os grupos percussivos, tendo como referência os sentidos da palavra "nação", e como ela foi ressignificada ao longo dos séculos XIX e XX. Também busca estabelecer diferentes questões para entender o maracatu-nação, a exemplo das suas fronteiras com os grupos percussivos bem como os sentidos de nação existentes nos maracatus "ditos tradicionais". Procura ainda definir o maracatu-nação mostrando suas fronteiras com os novos grupos da contemporaneidade, definidos como "grupos percussivos", e entender as diferenças bem como as tensões e negociações entre essas práticas culturais.

Palavras-chave: nação - maracatus-nação - grupos percussivos - cultura negra

\section{Abstract}

This article discusses the differences between maracatu nations (maracatus-nação) and percussion groups, using as a reference the meanings of the word "nation," and how it has been resignified over time. The article addresses different issues in order to understand maracatu-nação, its boundaries with percussion groups, as well as the meanings of nation in the first maracatus that constitute the boundaries between them. It is in this aspect that the article seeks to define maracatu-nação by what it is not, demonstrating its borders with the new contemporary groups, defined as "percussion groups." In addition to understanding the differences between maracatus-nação and the percussion groups, the article also succeeds in understanding the tensions and negotiations between these cultural practices.

Keywords: nation - maracatu-nação - percussion groups - black culture 